\title{
Cultural Contexts as Determinants of Speaker's Meaning in Culture-Specific Pragmatics
}

\author{
Kunjana Rahardi \\ \{kunjana.rahardi@gmail.com\} \\ Master of Indonesian Language and Literature Program, \\ Faculty of Teachers' Training and Education, Sanata Dharma University, Yogyakarta, Indonesia
}

\begin{abstract}
The speaker's meaning in pragmatics will never run out to explore. The speaker's meaning is embedded in the complex contexts surrounding the utterances and it keeps changing over time. One of the contexts is the cultural context, which plays a dominant role in the culture-specific pragmatics. This research is meant to explore the roles of cultural context in the culture-specific pragmatics. The research problem is then formulated as follows: (1) What are the elements found in the cultural context of the culture-specific pragmatics?; (2) What are the contextual functions embedded in the culture-specific pragmatics? The research data source is the utterances spoken in various domains within the culture-specific scope which includes elements and functions of cultural contexts. The research data uses excerpts of utterances taken from the conversational texts in different domains containing elements and functions of cultural contexts. The data is gathered using the observation and speaking methods, employing note-taking and recording techniques. The gathered data is analyzed using the distributional analytical method and pragmatic identity method. The research results show that cultural contexts in the culture-specific community have the following elements: (1) the speaker's cultural background, (2) the hearer's cultural background, (3) the prevailing cultural norms, (4) instruments and the cultural genres. The functions of cultural contexts found in this research are: (1) cultural contexts as determinants of the speaker's meaning; (2) cultural contexts as indicators to determine the speaker's meaning; and (3) the cultural contexts to affirm the speaker's meaning. This research is theoretically beneficial to develop the study of pragmatics, especially the culture-specific pragmatics.
\end{abstract}

Keywords: cultural contexts; culture-specific pragmatics; elements and functions of contexts

\section{Introduction}

The study of the speaker's meaning is very interesting to research. The speaker's meaning always changes according to the context of the conversation. In a certain situation, a particular utterance can be interpreted to have Meaning A, while at the same time, the same utterance can be interpreted to have Meaning B. The difference in interpretation depends largely on the contexts, especially external contexts. Thus, understanding the essence of external contexts is very important to grasp the exact meaning of the speaker. Failure to understand the external contexts will fail to grasp the speaker's meaning. There are various types of external contexts, and one context is closely connected [1];[2].

Due to the limitations of space in this article, only the cultural contexts will be discussed. The other types of contexts will be explained moderately, as they will be the focus of further research. As implied from the title, this article will discuss how cultural contexts determine the speaker's meaning in the culture-specific community, especially Javanese. The perspective 
used in this research is the pragmatic perspective, namely culture-specific pragmatics. General pragmatics will be contextualized so that it will be relevant to the linguistic entity in the culture-specific community [3].

The research question is formulated as follows: What are the elements and functions of cultural contexts which determine the speaker's meaning in communication? The research objective correlates with the formulated question, namely, to describe the forms and functions of cultural contexts that determine the speaker's meaning in communication. The research results will be beneficial to (a) raise awareness among the intercultural and cross-cultural interlocutors to understand the importance of cultural contexts in interpreting the speaker's meaning; (b) provide a medium and insight to pragmatic learners that the pragmatic principles, both general and specific, must be found through proper research procedures, instead of through merely reading existing references; (c) develop the general pragmatic theories based on the descriptive data available in the culture-specific community.

The underlying theory of this research is the context theory in pragmatics. Contexts are divided into two, namely, internal and external contexts [4]. Internal contexts include segmental and suprasegmental aspects. Segmental aspects include linguistic entities preceding and following the language entity being interpreted. Such a context is commonly known as cotext [5]. Besides co-text, suprasegmental aspects such as intonation, word stress, duration, length of speech to express the utterance may also affect the speaker's meaning. A group of experts in semantics-pragmatics espouses this view. They assume that pragmatics cannot be separated from the linguistic aspects, especially those interconnected with meaning, i.e., semantics.

Other proponents of pragmatics tend to remove intralinguistic contexts in interpreting the speaker's meaning. Therefore, there is a clear-cut division, in that the external contexts are the determinants of the speaker's meaning. The difference in the speaker's meaning as described at the beginning of this article is not determined by co-texts but by contexts. Contexts are classified into four, namely social contexts, societal contexts, situational contexts, and cultural contexts. Social contexts refer to horizontal social contexts [1].

Social contexts have egalitarian, collegial dimensions, and they remove social classes and status differences. Egalitarian relationships between farmers, colleagues, lecturers are clear examples of horizontal social dimensions. Societal contexts are not equal; it is vertical [6]. Relationships between employees and managers of a company, between patients and their doctors, between subordinates and their superiors in an institution are the concrete examples of the entity of the societal contexts.

Situational contexts depend largely on the situation, ambiance, atmosphere, etc. [7]. In a friendly and relaxed situation, someone's joke may be amusing and humorous that lightens up the day. However, under a different situation, context, and atmosphere, the same 'joke' may become a stumbling block or a problem that may result in a court battle. Many problems in society occur as a result of removing situational contexts in interpreting utterances.

Finally, the type of contexts being discussed in this article is cultural contexts. Understanding cultural contexts cannot be separated from discussing the community where the culture lives [8]. Culture and society are like two sides of a coin; they are inseparable. Aspects in cultural contexts cannot be separated from personal and communal assumptions shared in the society. Aspects of aesthetics, ethics, morality, and philosophy shared in the society are embedded in these assumptions.

Therefore, speaking of cultural contexts cannot be separated from the dimensions previously mentioned. Speaking of the speaker's meaning is not only interconnected with the theory of contexts as previously described, but also with the theory of pragmatics [9]. 
Essentially, a speaker's meaning is the focus of a pragmatic study. A linguistic study cannot be defined as a pragmatic study when it does not discuss the speaker's meaning. Pragmatics is commonly understood as the newest branch of the linguistic study, which studies the speaker's meaning. The general pragmatics usually bases its field of study on the linguistic data of the European languages, while culture-specific pragmatics bases the research data on the local languages.

Consequently, the research data source of the culture-specific pragmatic study of the speaker's meaning is the local language [10]. Furthermore, the speaker's meaning is understood based on social, societal, situational, and cultural contexts. Therefore, in this research, the pragmatic theory is used as the frame of reference, while the theory of context is used as the analytical tool.

\section{Research Methodology}

The proper research procedure is largely determined by the use of correct and appropriate research methodology. The research method focuses on instruments and procedures. Proper instruments and procedures will result in appropriate data, and provide appropriate analysis results. In addition, data mining is a crucial matter to be explained in the research methodology [11]. The data source of this research is excerpts of utterances in various culturespecific domains containing elements and functions of cultural contexts. The research data is excerpts of utterances from conversational texts in various domains containing elements and functions of cultural contexts. The data is gathered by applying the observation and speaking methods, both note-taking and recording techniques. The gathered data is then analyzed using the distributional analytical method and pragmatic identity method [12], [13]. Furthermore, the analysis result is presented using the informal method conducted using the descriptive verbal language, instead of using quantitative data and formula as commonly practiced in formal quantitative research.

\section{Research Results and Findings}

In line with the problem formulation, the discussion in this section is divided into two, namely those related to elements of contexts to answer the first question, and the functions of contexts to answer the second question. Specifically, the discussion of elements and functions of cultural contexts is presented as follows.

\subsection{Elements of Cultural Contexts}

Based on the preliminary research, there are three elements of contexts predominantly present in the cultural contexts; they are (1) elements of the speaker's and hearer's backgrounds, (2) elements of prevailing cultural norms, and (3) elements of cultural instruments and genres. In addition to the three elements of dominant contexts, there are elements of other cultural contexts, which will not be discussed at length in this short article due to the limitation of space. The three elements are described one by one as follows.

\subsubsection{Elements of the Speaker's and the Hearer's Cultural Backgrounds}


Elements of the speaker's and the hearer's backgrounds, and the person being spoken add colors to the speaker's meaning. An Excerpt of Utterance 1, the speaker, the hearer, and the person being spoken of are of the Javanese cultural background. Their Javanese cultural background is clearly manifested in the Javanese-nuanced utterances, such as 'po' [Do you?] in 'Atau mau sekarang po?" [Do you want to do it now?"]. In the Javanese, "po" can be categorized as a pragmatic phatic marker. The forms " $p o$ " is the same as " $t o$ ", which is written as ' $p a$ ' or ' $a p a$ '. In the informal language use, the forms ' $p o$ ' and 'opo' [what] manifests as 'kan' [right?] as in 'Iya, kan?' [It's true, right?] or 'Tidak demikian, kan?' [It's not true, right?]. In the following excerpt, the form 'ngko' in the utterance 'Ngko, habis ini.' [Later, after this] can be categorized as a pragmatic phatic marker [14].

In the Indonesian language, 'ngko' manifests into'nanti' [later], and in a very informal form 'ntar' [later]. Two linguistic forms prove that the speaker and the hearer in the conversation have a Javanese cultural background. However, the Javanese markers do not only manifest in the form of the utterance, but also in the nuance of the utterance. The Javanese people are stereotypically relaxed and laid-back, unlike the stereotypical description of the Bataknese, the Malay, the Papuans, etc. The laid-back Javanese character can be seen in the following Excerpt of Utterance 1. The speaker conveyed her intention to the hearer as she was busy doing her work. The utterance was conveyed casually because the speaker's attention was on his work. The hearer was not disturbed by the perfunctory manner of her speech. The conversation was done in a relaxed manner.

It appears in the following form 'Ntar kamu mau diskusi sama Pak Kun jam berapa?' [When will you discuss with Mr. Kun?] and the hearer says 'Ngko, habis ini. Atau mau sekarang po?' [Later, after this. Or do you want to do it now?] Finally, the manifestation of the relaxed atmosphere is in the form of this expression, 'Hmm...nanti dulu ah...baru nanggung nih..' [Hmmm...maybe later...I'm in the middle of something]. Therefore, it can be said that the speaker's meaning in the utterance is highly influenced by the speaker's and the hearer's cultural background. The Javanese cultural background signals relaxedness [15]. In addition to being laid-back, the Javanese are also polite, indirect, and reticent. These Javanese characteristics are not manifested in the following utterance. To understand this further, the readers can read the Excerpt of Utterance 1.

\section{Excerpt of Utterance 1}

$P$ : Ntar kamu mau diskusi sama Pak Kun jam berapa? (sambil mengerjakan tugas) MT: Ngko, habis ini. Atau mau sekarang po? Mumpung masih ada waktu setengah jam. P: Hmm nanti dulu ah... baru nanggung nih...

S: When will you discuss with Mr. Kun?

H: Later, after this. Or do you want to do it now?

$\mathrm{S}$ : Hmmm...maybe later...I'm in the middle of something...

Context of Utterance:

The speaker and the hearer are 19-year-old fourth-semester Javanese students. The class was very noisy and the weather was hot and humid. The speaker asked the hearer when she would meet the lecturer. The speaker's question was addressed to the hearer casually because she did not have plans to meet the lecturer at that exact moment. As a result, the speaker refused to see the lecturer at that time. 



\title{
3.1.2 The Prevailing Cultural Norms
}

The prevailing cultural norms in society add colors to the interpretation of the speaker's meaning in a communicative event. An Excerpt of Utterance 2, the speaker and the hearer have non-Javanese cultural backgrounds. They are from Jakarta and even though they have lived in Yogyakarta for quite a while, their language and speech are still heavily nuanced with the Jakartan style. This is evident in the use of the forms 'elu' and 'elo' in the speaker's and hearer's speech. Besides, the typical Jakartan-styled forms 'deh' and 'gua' and 'gue' are clearly manifested in their speech.

The other forms confirming that the speaker and the hearer have Jakartan cultural background can be seen in the form 'ngekirim' [sending] and the diction 'kabur' [ran away] to replace 'pergi' [went] atau 'berangkat' [left]. The speech style of the linguistic forms shows, undeniably, that the speakers must not be from the Javanese cultural backgrounds. Instead, it is highly likely that Jakartan speakers speak the metropolitan speech style. The prevailing norms to interpret the speaker's meaning are divided into two, namely, norms of interaction and norms of interpretation [16]. In interpreting the speaker's meaning, the norms of interaction based on cultural backgrounds are worth noting. The Javanese norms of interaction are dominated by politeness, polite non-verbal cues, and gentle voice and soft-spoken demeanor.

However, the norms of the interaction of the people of the Jakartan background tend to use less non-verbal language as indicators of politeness. They usually speak loudly as if they were shouting. They usually gaze the hearers when speaking, unlike the Javanese people who lower their heads and avoid eye-contact when speaking. The Javanese people define such people to have a 'sregal-sregel' character in speech and demeanor. In conclusion, understanding the norms of interaction based on cultural backgrounds is very important to interpret the speaker's meaning. Further, Excerpt of Utterance 2 will clarify the point.

\section{Excerpt of Utterance 2}

\author{
Penutur : Pris, elu nggak kabur ke Kopma sekarang? \\ Mitra Tutur : Gue mau ikut elo aja dech! Tapi bentar yah...., gua ngekirim ini dulu. Bentar \\ yah...
}

S: Pris, you wanna run away to Kopma now?

H: It's up to you! But hold on...., let me send this first. Just a sec, 'kay?

\section{Context of utterance:}

The speaker and hearer are 19-year-old fourth-semester female students. Both speaker and hearer are from Jakarta and have a metropolitan cultural background. The conversation took place at 8.45 a.m., and it was the transition between the first lesson to the second one. The speaker asked the hearer, who always went to the Co-operative shop during recess. The speaker's question was an invitation to accompany her to the Co-operative shop. The hearer did not respond immediately to the invitation and asked the speaker to wait patiently. The hearer would leave as soon as the work was done. 


\subsubsection{Cultural Instruments and Genres}

The third dominant element of cultural contexts is elements of cultural instruments and genres [17]. The language used by the people of the Javanese cultural background tends to be soft-spoken, subtle, and not 'centhang-centheng'. 'Centhang-centheng' means outspoken, blunt, and unreserved. People who are 'centhang-centheng' are characterized by 'ceplasceplos' [calling a spade a spade], unreserved, point-blank or 'ora tedheng aling-aling' [brutally honest]. In many circumstances, such a way of speaking is hurtful because this manner of speech is not considered a common characteristic of the Eastern people.

An Excerpt of Utterance 3, the speaker and the hearer are from a region in Central Java. People from these areas have different cultural backgrounds from the people from outside Java who tend to be outspoken and loud. The people from Central Java tend to use many pleasantries, like the people from Yogyakarta. The form 'Makasih yaa sayaaangggg...dada....' [Thanks, darling. Good bye]. The following excerpt shows that the relationship between the speaker and the hearer is very close. Due to their closeness, it was hard for them to be separated from each other. The previous utterance was spoken to show reluctance to be separated from each other. The hearer's response was 'Iyaa. Hati-hati ya. Dada...' [Okay. Take care, okay? Byeeee...]. It shows that her relationship with the speaker is very close and intimate.

The writer wants to emphasize that the instrument and genre of the utterance as seen in the excerpt of utterance influence the interpretation of the speaker's meaning. The relaxed, intimate, polite, indirect, subtle genre of utterance is the characteristic of the samudana [pretense, façade, lip-service, hypocrisy] culture [15]. As for the genre of utterance characterized as 'ceplas-ceplos', 'sregal-sregel' dan 'srugal-srugel', these are usually the characters of the culture that stresses the importance of directness and frankness. The excerpt of Utterance 3 will illustrate that.

\section{Excerpt of Utterance 3}

P: Makasih yaa sayanggg... Dada....
MT : Iyaa. Hati-hati ya...Dada...
P: Iya hati-hati, makasih...
S: Thank you, darling. Good byee...
H: Okay. Take care, okay? Byeee
S: Okay. Take care...thank you...
Context of Utterance:
The speaker is a 19-year-old fourth-semester female student. She comes from a city in Central
Java. The hearer is a 20 -year-old fourth-semester female student. The conversation took place
in the afternoon in a classroom on the second floor. The speaker thanked the hearer and said
goodbye to the hearer who had seen her off to her classroom.

\subsection{Functions of Cultural Contexts}

Based on the writer's observation through the preliminary research, there are at least three functions of cultural contexts in communication. The three functions are respectively described as follows: (1) cultural contexts as determinants of the speaker's meaning, (2) cultural contexts as indicators to determine the speaker's meaning, and (3) cultural contexts as 
the confirmation of the speaker's meaning. In the following section, each function of cultural contexts will be presented one by one.

\subsubsection{Cultural Contexts as Determinants of the Speaker's Meaning}

From the preliminary research, it was found that the primary function of cultural contexts is to determine the speaker's meaning in communication. It is said so because once the cultural contexts are removed, the speaker's meaning cannot be properly identified. The Javanese people who believe in indirectness and subtleness tend to exhibit unspoken intention in communicating with the hearer [18]. For example, despite being angry and disappointed with the situation in his region, a Javanese aristocrat is likely to be silent and taciturn.

However, the subjects/subordinates who share the same cultural background will understand the 'silence' and 'reticence' displayed by the aristocratic leader. When visiting someone whose living room is hot and humid, it will be impolite for a Javanese to comment "It's very hot, isn't it?" or "It's very dark in here, isn't it?' because he/she knows that the comment will hurt the host's feeling. He/she will never ask someone to open a window or a door to let the air in or to turn on the light to illuminate the darkroom. Javanese people are aware that such orders will cause the homeowners to lose face.

However, people who have other cultural backgrounds may not be aware of this shared culture. It is possible that they would complain loudly and noisily of the heat and stuffiness of the room and would order someone to do something to make the room cooler and brighter. They may not realize that the orders have caused the host to lose face and the person who is ordered to open a window might feel uncomfortable. In other words, the non-Javanese guests have caused two people to lose face. In the Excerpt of Utterance 4, the speaker's cultural background has made them loud, emotional, and temperamental. Their cultural upbringing has made them utter this sentence, 'Oke, terima kasih atas perkuliahan ini. Lain kali jangan ramai sendiri seperti ini ya. Menjengkelkan. Mari kita tutup dengan doa.' [Okay. Thank you for being here. Next time, don't be so noisy as you did today, okay. It's so annoying. Now, let us close this with a prayer.]

\section{Excerpt of Utterance 4}

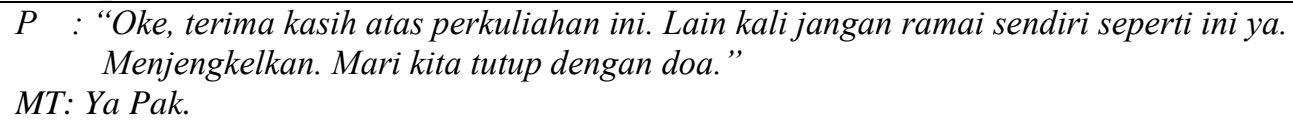

S: Okay. Thank you for being here. Next time, don't be so noisy as you did today, okay. It's so annoying. Now, let us close this with a prayer.

$\mathrm{H}$ : Yes, sir.

Context of Utterance:

The speaker is a 29-year-old male lecturer in History Education. The hearer is a 19-year-old male student who sat very close to where the speaker stood. The class took place in the afternoon and the utterance was spoken at the end of a class. The speaker invited the students to end the class with a prayer. The hearer answered sprightly and loudly.

\subsubsection{Cultural Contexts as Indicators to Determine the Speaker's Meaning}


In the previous discussion, cultural contexts can be used to determine the speaker's meaning, as seen in the Excerpt of Utterance 5. That excerpt suggests that by examining the cultural background, we can indicate the speaker's and hearer's meaning in their speech. For example, someone who comes from a cultural background that appreciates humor and joking will help the speaker and hearer to understand the speaker's meaning being conveyed [19].

Therefore, responses to the speaker and hearer can be predicted from what is indicated, be they humor or joking. Another example is when you visit a family of a certain ethnicity. The cultural contexts of the visitors and the hosts will determine the language use. Madurese people tend to speak loudly, unlike the Javanese people who tend to speak softly and subtly. A Javanese host entertaining guests of the Madurese people must be prepared with this cultural knowledge. Likewise, before accepting guests from Papua, a Javanese host must prepare himself to understand the cultural background of his guests.

An Excerpt of Utterance 5, the situation is relaxed, humorous, and an utterance was spoken 'Ya kreatif dikit kan bisa.' [Well, a little creative won't hurt.] This utterance was spoken when the hearer said 'Gak punya TV, Pak.' [I don't have TV, sir.]. It indicates that someone's cultural background indicates the utterance to be said. In other words, information on the speaker's cultural background can indicate the speaker's meaning. Further on this matter, Excerpt of Utterance 5 illustrates the point.

\section{Excerpt of Utterance 5}

$P$ : "Pada tanggal 30 September kemarin ada berita yang cukup menarik ya di TV One terkait dengan apakah negara harus minta maaf dengan para korban dan lain sebagainya. Dan seharusnya Anda menontonnya."

MT: "Gak punya TV, Pak."

$P$ : "Ya kreatif dikit kan bisa."

(Seluruh kelas tertawa)

S: On September 30, there was interesting news on TV One related to whether the State must apologize to the victims of the G30S Coup d'etat. You should have watched it.

$\mathrm{H}$ : I don't have TV, sir.

S: Well, a little creative won't hurt.

Context of Utterance:

The speaker is a 30-year-old Javanese male lecturer at the History Education department. The hearer is a 20-year-old male student. The conversation took place seriously in the classroom. The speaker wanted to explain the event connected to the failed coup d'etat attempt on September 30, 1965. The speaker started by citing the news from the television. Suddenly the hearer responded to the speaker's explanation. Then, the speaker jokingly asked the hearer to be more creative to find the news.

\subsubsection{Cultural Contexts as the Confirmation of the Speaker's Meaning}

The dominant third function of cultural contexts is the confirmation of the speaker's meaning. One of the negative dimensions of the Javanese people is that they find it hard to say 'no.' Saying no for the Javanese people is hard even when they have an objection. Without knowing what a person feels, his/her cultural background can be used to confirm what he might feel in a certain situation. Good hearers must understand the cultural background so that they will not feel imposed [20]. 
In the relationships between employees and managers, for instance, it is crucial to understand the cultural background of the employees and the managers. The Javanese employees might feel pressured working under a manager from the Batak ethnicity. In contrast, Batak employees might have to make a lot of adjustments working under Sundanese or Javanese superiors. It is clear, thus, that the speaker's cultural background functions to reinforce the speaker's meaning. This can be seen from the Excerpt of Utterance 6 as follows, where the hearer speaks firmly and sternly to the students. Her assertive and curt answers did not imply that she was annoyed with the students. It was just the way she spoke as a Bataknese person because she was raised culturally to speak that way.

\title{
Excerpt of Utterance 6
}

\author{
$P$ : “Aduh Bapak.." \\ $M T$ : "Hah, kenapa? Aduh-aduh segala!" \\ $P$ : Katanya gak ada UTS." \\ MT : Iya biar surprise. Lagian, biar kapok lu!"
}

S: Oh, my God. Sir...

H: What's up? What's with 'Oh, my God?'

S: You said there will be no midterm test.

H: Yes, it's a surprise. On second thought, I hope you've learned your lessons!

Context of Utterance:

The speaker is a 19-year-old male student. The hearer is a 29 -year-old male lecturer from the Mathematics Department. The conversation took place in the class in the afternoon. The speaker expressed his disappointment. The hearer was surprised to hear the student's exclamation of disappointment. The speaker hoped that there was no midterm test, but the hearer already distributed the test sheets and it was a pleasant surprise for the hearer.

\section{Conclusion}

In a nutshell, it can be concluded that this research found three basic elements of cultural contexts, namely (1) the speaker's and the hearer's cultural backgrounds, (2) the prevailing cultural norms, and (3) the cultural instruments and genres. The three functions of cultural contexts are: (a) cultural contexts as the determinants of the speaker's meaning, (b) cultural contexts as indicators determining the speaker's meaning, (c) cultural contexts to confirm the speaker's meaning. The findings of the elements and functions of cultural contexts above assert that cultural contexts are crucial in the study of pragmatics. Cultural contexts determine the speaker's meaning in the study of pragmatics. The general pragmatics enriched with culture-specific pragmatics as in the research conducted above, will clarify the principles of general pragmatics so that the study of pragmatics in Indonesia will develop rapidly in terms of research performances.

\section{Acknowledgment}

This research work is supported by DRPM, Ministry of Research, Technology, and Higher Education, The Republic of Indonesia. The writer thanks for the continual supports given for more than six consecutive years. 



\section{REFERENCES}

[1] R. K. Rahardi, "MANIFESTASI WUJUD DAN MAKNA PRAGMATIK KEFATISAN BERBAHASA DALAM RANAH PENDIDIKAN," Adab. J. Bhs. dan Sastra, 2016.

[2] S. R. Barley, G. W. Meyer, and D. C. Gash, "Cultures of Culture: Academics, Practitioners and the Pragmatics of Normative Control," Adm. Sci. Q., 2006.

[3] Y. Widiana, "A Sociopragmatics Study on Social Criticism in Meme Comics," in Kajian Pragmatik dalm Berbagai Bidang, 2015.

[4] M. Wildner-Bassett, "Context and Culture in Language Teaching and Learning," Stud. Second Lang. Acquis., 2004.

[5] L. Mao, "Pragmatics: An introduction," J. Pragmat., 2003.

[6] L. R. Waugh, T. Catalano, K. Al Masaeed, T. H. Do, and P. G. Renigar, "Critical discourse analysis: Definition, approaches, relation to pragmatics, critique, and trends," in Perspectives in Pragmatics, Philosophy and Psychology, 2016.

[7] C. F. Meyer, M. A. K. Halliday, and R. Hasan, "Language, Context, and Text: Aspects of Language in a Social-Semiotic Perspective," TESOL Q., 2006.

[8] J. Chen, "Research Trends in Intercultural Pragmatics," Aust. J. Linguist., 2017.

[9] K. Rahardi, "Personal and Communal Assumptions to Determine Pragmatic Meanings of Phatic Functions," Ling. Cult., vol. 10, no. 2, p. 95, 2016.

[10] K. A. Yu, "Culture-specific concepts of politeness: Indirectness and politeness in English, Hebrew, and Korean requests," Intercult. Pragmat., 2011.

[11] A. K. Harrison, Ethnography. 2018.

[12] Sudaryanto, Metode dan Aneka Teknik Analisis Bahasa, 1st ed. Yogyakarta: Sanata Dharma University Press, 2016.

[13] M. Mahsun, "Metode Penelitian Bahasa," Jakarta PT Raja Grafindo Persada, 2005.

[14] C. Goddard, "“Early interactions' in Australian English, American English, and English English: Cultural differences and cultural scripts," J. Pragmat., 2012.

[15] B. Anderson, "The Idea of Power in Javanese Culture," Cult. Polit. Indones., 1972.

[16] M. M. Webster and A. J. W. Ward, "Personality and social context," Biological Reviews. 2011.

[17] S. Sorlin, "The pragmatics of manipulation: Exploiting im/politeness theories," $J$. Pragmat., 2017.

[18] E. T. Herliana, "Preserving Javanese Culture through Retail Activities in Pasar Beringharjo, Yogyakarta," Procedia - Soc. Behav. Sci., 2015.

[19] J. A. Matisoff and A. Wierzbicka, "Cross-Cultural Pragmatics: The Semantics of Human Interaction,” Language (Baltim)., 2006.

[20] Wibowo dkk., "Kearifan Lokal dalam Menjaga Lingkungan Hidup (Studi Kasus Masyarakat di Desa Colo Kecamatan Dawe Kabupaten Kudus),” J. Educ. Soc. Stud., 2012. 